\title{
Suppressive biomasses and antagonist bacteria for an eco-compatible control of Verticillium dahliae on nursery-grown olive plants
}

\author{
D. Vitullo $\cdot$ R. Altieri $\cdot$ A. Esposito \\ F. Nigro $\cdot$ M. Ferrara $\cdot$ G. Alfano $\cdot$ G. Ranalli $\cdot$ \\ V. De Cicco $\cdot$ G. Lima
}

Received: 14 October 2011/Revised: 29 January 2012/Accepted: 1 March 2012/Published online: 25 December 2012

(C) CEERS, IAU 2012

\begin{abstract}
Two organic amendments (OMW-M1 and OMW-M2), based on olive mill wastes (OMWs) subjected to advanced processes of aerobic static storage or composting, were tested for their suppressive activity against Verticillium dahliae, the causal agent of olive Verticillium wilt. OMWM1 and OMW-M2 drastically inhibited the pathogen growth in vitro and then were further tested in suppressive pot experiments. The amendments, mixed at $15 \%(\mathrm{v} / \mathrm{v})$ with a nursery standard plant-growth matrix, were tested alone or in combination with two biocontrol bacteria (Bacillus amyloliquefaciens and Burkholderia cepacia) selected from suppressive soils. All mixtures were artificially contaminated with $V$. dahliae microsclerotia (MS), the density of which was periodically monitored by either a semi-selective medium or a specific real-time Polymerase Chain Reaction technique. In plant-less pot assays conducted in a growth chamber, OMW-M1 was the most effective amendment, reducing $V$. dahliae MS density by $100 \%$ after 90 days with respect to the untreated control. In nursery experiments with pot-growing olive plants, OMW-M1, particularly when
\end{abstract}

D. Vitullo $\cdot$ V. De Cicco $\cdot$ G. Lima $(\bowtie)$

Department of Agricultural, Environmental and Food Sciences, University of Molise, Campobasso, Italy

e-mail: lima@unimol.it

R. Altieri · A. Esposito

Institute for Agriculture and Forest Systems

in the Mediterranean, National Research Council, Perugia, Italy

F. Nigro - M. Ferrara

Department of Soil, Plant, and Food Sciences,

University of Bari "Aldo Moro", Bari, Italy

G. Alfano · G. Ranalli

Department of Bioscience and Territory, University of Molise, Pesche, IS, Italy combined with the biocontrol bacteria, confirmed its strong suppressive activity reducing up to $100 \%$ the density of $V$. dahliae MS in the rhizosphere behaving even better than a commercial biofungicide (Trichoderma asperellum TV1) used as a control. The best combined treatment also reduced plant mortality and increased root and shoot extension. It is concluded that organic amendments from stabilized olive mill by-products showed positive agronomic and phytosanitary properties on pot-growing olive plants and, particularly when enriched with biocontrol agents, they are potentially suitable for use in sustainable agriculture.

Keywords Biocontrol agents - Olea europaea - Olive mill wastes $\cdot$ Soilborne plant pathogens $\cdot$ Suppressive plant growth media

\section{Introduction}

Verticillium dahliae is a well-known and widespread soilborne fungal pathogen causing wilting of olive and several other important crops. Increasing frequency and severity of Verticillium wilt has been recorded in nursery as well as in open field cultivations over the last decades. Pathogen control is very difficult since it may persist for several years in contaminated soils by quiescent resting structures known as microsclerotia, and the use of synthetic fungicides against the pathogen raises technical and environmental concerns (Jiménez-Díaz et al. 1998; Nigro et al. 2005). Moreover, the ban of methyl bromide, the most effective and widely used pesticide for soil disinfestations, has further stimulated research into the use of alternative tools for controlling soilborne plant pathogens (Martin 2003). For these reasons it is necessary to develop and test new environmentally friendly alternative methods. 
In recent years considerable research efforts on alternative methods to control plant pathogens have been spent on evaluating biocontrol agents as well as composts and other organic amendments (OAs) obtained from various cured agri-food by-products.

Composts and cured organic amendments are under study, not only for their beneficial effects on chemical, physical, biological and physiological properties on both soil and plant (Alburquerque et al. 2007; Altieri and Esposito 2010; López-Piñeiro et al. 2007; Senesi et al. 2007; Walker and Bernal 2008), but also for their suppressive effects against plant pathogens (Alfano et al. 2009a; Boulter et al. 2002; Noble and Coventry 2005; van der Gaag et al. 2007). Recently, close attention was paid to studies regarding re-usage in agriculture as amendments and/or organic fertilizer of olive mill wastes (OMWs) derived from olive oil production (around $2.9 \times 10^{6}$ tons per year, coming mainly from Mediterranean countries) which continues to increase worldwide (IOOC 2012). Therefore, disposal of OMWs, produced at a rate in excess of $10 \times 10^{6}$ ton per year, is becoming an environmental challenge (Alfano et al. 2009b).

As regard biocontrol agents, a large number of plantbeneficial microorganisms (e.g., bacteria, filamentous fungi, yeasts and yeast-like fungi) have been reported to protect plants from several plant pathogens (De Costa et al. 2008; Haas and Défago 2005; Lima and De Cicco 2006), also including V. dahliae (Mercado-Blanco et al. 2004; Yaseen et al. 2009).

However, the prevention of $V$. dahliae by adding organic amendments and antagonistic microorganisms in the plant growing matrices has not been extensively investigated. Moreover, the implementation of organic farming systems also in the olive nursery production requires new and ecocompatible methods to produce organic plantlets. Therefore, there is an urgent need to improve knowledge on effective strategies to prevent Verticillium wilt in the nursery using optimized suppressive matrices.

The aim of this study was to assess the suppressiveness against $V$. dahliae of two selected organic amendments, based on OMWs and biocontrol bacteria, as well as to elucidate the mechanisms involved in their suppressive effect. The present research was carried out during the years 2008, 2009 and 2010 in the Molise Region of Italy.

\section{Materials and methods}

Organic amendments

According to our previous preliminary investigations by which different organic by-products were screened for their potential suppressiveness against soilborne fungal pathogens, two organic amendments containing OMWs, labelled as OMW-M1 and OMW-M2, were selected for experiments carried out in the present research.

OMW-M1 was obtained from a two-phase mill at the Cooperativa Nuova Cilento, San Mauro Cilento, Salerno (Italy) as described by Altieri et al. (2005). Briefly, the humid olive husk, previously destoned, was mixed with hygroscopic organic wastes by a prototype machine as follows: $11.0 \%$ waste wool, $8.5 \%$ straw and $8.5 \%$ sawdust. The percentages of these ingredients were used on a fresh weight basis. The OMW-M1 mixture was packed in net sacks, stored outdoors on pallets in stacks allowing for natural aerobic microbial activity. They were protected from rain and used after 3 months of static aerobic storage.

OMW-M2 was produced at the industrial-scale composting plant "SETA Srl, Servizi Territorio Ambiente," in Vigonza, Padova (Italy). A composting pile (20 m length, $1.9 \mathrm{~m}$ width and $1.5 \mathrm{~m}$ height) was made by mixing wet olive husks $(30 \% \mathrm{w} / \mathrm{w})$ from a two-phase olive oil extraction plant, green residues from maintenance of municipal parks $(60 \% \mathrm{w} / \mathrm{w})$ and sewage sludge $(10 \% \mathrm{w} / \mathrm{w})$ from a municipal wastewater treatment plant of the city of Verona (Italy). The process was carried out on a concrete slab in a confined environment. The composting process lasted 75 days: 35 days of forced bio-oxidation through mechanical pile turnover every 2-3 days, followed by a curing phase of 40 days in static piles. Pile turning operations were carried out with an industrial turning machine (Seko, Curtarolo, Italy) which slowly moves forward across the pile while turning the residues with an endless screw.

Physical, chemical and biological analyses of OAs

Representative samples were collected for analyses at the end of maturation period: 90 days for OMW-M1 and 75 days for OMW-M2, respectively.

Water extracts of fresh samples 1:10 (w/v) were collected in triplicates and tested for electrical conductivity (EC), $\mathrm{pH}$ and polyphenols. Total organic carbon was determined by the Springer-Klee method and total nitrogen by the Kjeldhal method (DIVAPRA and IPLA 1992). The ash content was determined as weight loss, on samples previously oven dried at $105{ }^{\circ} \mathrm{C}$ for $24 \mathrm{~h}$ and following in a muffle furnace at $650{ }^{\circ} \mathrm{C}$ for $6 \mathrm{~h}$. Cation exchange capacity (CEC) was determined according to procedures reported in DIVAPRA and IPLA (1992). Total polyphenols (TP) were determined using the Folin-Ciocalteu method as reported by Singleton et al. (1971). After acid digestion (nitric and perchloric acid 2:1 v/v), potassium, calcium, and magnesium were measured by flame atomic spectroscopy (Perkin-Elmer, AAnalyst 200) while phosphorus, after successive colour-metering, as molybdovanadate phosphoric acid (Murphy and Riley 1962).

Total fat was determined by extraction of samples $(8 \mathrm{~g})$ added with anhydrous sodium sulphate $(40 \mathrm{~g})$ in hexane 
(100 ml). After homogenization with an Ultraturrax homogenizer (IKA T25), the supernatant was recovered by centrifugation $(5,000 \mathrm{rpm}$ for $15 \mathrm{~min})$ and concentrated using a Rotavapor (Buchi R110). The residual fatty matter, recovered in a vial, underwent sparging with $\mathrm{N}_{2}$ to constant weight. All values were expressed as percentage of dry matter.

Humic substances were extracted from ground air-dried compost samples $(<0.5 \mathrm{~mm})$ with $0.1 \mathrm{M} \mathrm{NaOH}$ and $\mathrm{Na}_{4} \mathrm{P}_{2} \mathrm{O}_{7}(1: 50 \mathrm{w} / \mathrm{v})$. The samples, placed in sealed bottles under $\mathrm{N}_{2}$ atmosphere, were shaken in a thermostatic Dubnoff bath for $24 \mathrm{~h}$ at $65{ }^{\circ} \mathrm{C}$. They were centrifuged for $20 \mathrm{~min}$ at 5,000 rpm; the supernatant (total alkali-extractable fraction) was carefully removed and adjusted to $\mathrm{pH}$ 2.0 by adding concentrated $\mathrm{H}_{2} \mathrm{SO}_{4}$. The precipitate (humiclike acids, HA) was allowed to coagulate for a few minutes and then separated by centrifugation from the supernatant which contains the fulvic acid (FA) and non-humic (NH) fractions. The separation of $\mathrm{NH}$ from FA was carried out according to Sequi et al. (1986) using a column packed with polyvinylpyrrolidone. HA and FA portions were recombined and analyzed for carbon content and expressed as humic carbon.

The phytotoxicity of OMW-M1 and OMW-M2 was tested by evaluating the Germination Index (GI) of Lepidium sativum L. selected seeds in water extracts of the amendments (Ranalli et al. 2001; Zucconi et al. 1981). Briefly, deionized water was added to the samples to achieve 50 and $75 \%$ of water content (wet weight); they were shaken for $1 \mathrm{~h}$ and extracts were obtained by centrifugation and filtration through a $0.45-\mu \mathrm{m}$ membrane filter. The extracts were diluted $(30 \%)$ and used as the germination medium. A Whatman filter paper (n. 42), placed inside a 9-cm Petri dish, was wetted by $1 \mathrm{ml}$ of the medium, and nine seeds of L. sativum were placed on the paper. Pure deionized water was used as the control germination medium and five replicates were used for each treatment. The dishes were wrapped in Parafilm M, to minimize water loss and allow air penetration, and kept in the dark for $42 \mathrm{~h}$ at $24{ }^{\circ} \mathrm{C}$. At the end of incubation, the number of germinated seeds and primary root lengths were measured and expressed as percentage of GI in the control. The averages of the GI at different dilutions (50 and $75 \%$ ) were calculated using the following equations: GI (50-75\%) \%= $(\mathrm{Gc} \times \mathrm{Lc} / \mathrm{Gt} \times \mathrm{Lt}) \times 100$, where $\mathrm{Gc}=$ mean seeds germinated on sample, $\mathrm{Gt}=$ mean seeds germinated on control, $\mathrm{Lc}=$ mean length roots on sample, $\mathrm{Lt}=$ mean length roots on control, GI $\%=($ GI $50 \%+$ GI $75 \%) / 2$.

Microorganisms and growth condition

Pathogen Two strains (V1 and V9) of V. dahliae, isolated from the wood of infected olive trees in Apulia (Italy), were used to prepare microsclerotial suspensions to be used for artificial contamination of the experimental matrices. For biomass production, $V$. dahliae was routinely cultivated at $25{ }^{\circ} \mathrm{C}$ on Potato Dextrose Agar or Broth (PDA or $\mathrm{PDB}$, respectively) prepared with fresh potatoes. The MS were obtained on agarized media according to Hawke and Lazarovits (1994): briefly, the fungus was grown in the dark for 3-4 weeks at $24{ }^{\circ} \mathrm{C}$ on solid medium covered with sterile cellophane discs. After incubation the cellophane discs containing the microsclerotia were removed from the agar, suspended in sterile distilled water (SDW) and homogenized by an ultraturrax for $20 \mathrm{~s}$. The mixture was filtered through a layer of cheesecloth to remove cellophane residues, and the microsclerotial suspensions were filtered through three overlapping metal sieves with a mesh size of 250, 150 and $32 \mu \mathrm{m}$, respectively. The MS retained in the lower sieve (mesh size $32 \mu \mathrm{m}$ ) were re-suspended in an appropriate amount of SDW, and MS concentrations were adjusted by an haemocytometer.

Antagonist microorganisms The antagonist bacteria used in in vitro experiments were isolated from suppressive soil according to the methodology described by Berg et al. (2006) with some modification. Briefly, $45 \mathrm{ml}$ of SDW were added to $5 \mathrm{~g}$ of soil, shaken at $150 \mathrm{rpm}$ for $30 \mathrm{~min}$ at room temperature, centrifuged at $4000 \mathrm{rpm}$ for $5 \mathrm{~min}$, and after suitable serial dilutions (from $10^{-3}$ to $10^{-8}$ ), $100 \mu$ l of the supernatant were plated on agarized media (Nutrient Agar and King's B). Plates were incubated for 2 days at $25^{\circ} \mathrm{C}$ and the bacterial colonies grown in each plate were counted and used to calculate the cfu (colony forming units) per gram of the fresh weight of soil. Several bacterial isolates per treatment, location and sampling time were randomly selected.

Only few selected bacterial isolates were characterized by the routine bacteriological tests Biolog $^{\circledR}$ and API (Borrero et al. 2006) and by sequencing the small $16 \mathrm{~S}$ ribosomal subunit (Centraalbureau voor Schimmelcultures, The Netherlands, CBS). In particular, among the most effective antagonists, strains BO7 and BTd1 were identified as Bacillus amyloliquefaciens and Burkholderia cepacia, respectively. These strains were routinely cultivated in Minimum Salt Liquid Medium (MSLM: $\mathrm{K}_{2} \mathrm{HPO}_{4}$ $2.5 \mathrm{~g} \mathrm{~L}^{-1} ; \mathrm{KH}_{2} \mathrm{PO}_{4} 2.5 \mathrm{~g} \mathrm{~L}^{-1} ;\left(\mathrm{NH}_{4}\right)_{2} \mathrm{HPO}_{4} 2.5 \mathrm{~g} \mathrm{~L}^{-1}$; $\mathrm{MgSO}_{4} \times 7 \mathrm{H}_{2} \mathrm{O} 0.2 \mathrm{~g} \mathrm{~L}^{-1} ; \mathrm{FeSO}_{4} \times 7 \mathrm{H}_{2} \mathrm{O} 0.01 \mathrm{~g} \mathrm{~L}^{-1}$; $\mathrm{MnSO}_{4} \times 7 \mathrm{H}_{2} \mathrm{O} 0.007 \mathrm{~g} \mathrm{~L}^{-1} ; 10 \mathrm{~g} \mathrm{~L}^{-1}$ of glucose for Bacillus sp. or Burkholderia sp., respectively; $\mathrm{pH} 7.5$ ) at $28{ }^{\circ} \mathrm{C}$ and $120 \mathrm{rpm}$. A crude culture filtrate from each bacterial strain was obtained by centrifugation at $14,000 \mathrm{rpm}$ for $5 \mathrm{~min}$ and sterilization by filtration $(0.22 \mu \mathrm{m}$ pore size $)$. Bacterial cells were re-suspended in sterile PBS ( $\mathrm{NaCl} 170 \mathrm{mM}, \mathrm{KCl} 3 \mathrm{mM}, \mathrm{Na}_{2} \mathrm{HPO}_{4} 12 \mathrm{mM}$, $\mathrm{KH}_{2} \mathrm{PO}_{4} 4 \mathrm{mM}$; pH 7.4) (Sambrook et al. 1989) and cell concentration was adjusted spectrophotometrically $(600 \mathrm{~nm})$. Bacterial strains were suspended in $30 \%$ glycerol and stored at $-80{ }^{\circ} \mathrm{C}$. 
Water extracts of the amendments OMW-M1 and OMW-M2 (OAWEs), prepared according to Huang et al. (2006), were used in 96-well microtiter-plates experiments. OAWEs were prepared using the following steps: $10 \mathrm{~g}$ of dry organic amendments were suspended in $300 \mathrm{ml}$ SDW and shaken for $24 \mathrm{~h}$ at $100 \mathrm{rpm}$ at $4{ }^{\circ} \mathrm{C}$. The suspension was briefly centrifuged and filtered by using Whatman filter paper n. 1, and then divided into three aliquots. The first AOWEs sample was sterilized by filtration at $0.22 \mu \mathrm{m}$, the second one was boiled for $10 \mathrm{~min}$, while the remaining one was used untreated. All the samples were kept at $4{ }^{\circ} \mathrm{C}$.

As a control, the commercial biofungicide Xedavir ${ }^{\circledR}$, based on the antagonist fungus Trichoderma asperellum, strain TV1, provided by Xeda Italia s.r.1., Forlì (Italy), was used in the pot experiments.

In vitro activity of biocontrol agents (BCAs) and organic amendments water extracts (OAWEs) against $V$. dahliae

In order to assess the activity against $V$. dahliae of BCAs and OAWEs, in vitro assays on solid and liquid media were carried out.

Different bacterial strains (BO7, BTd1, 588, BTd35, BT4, BO5A, BO6, BT23A, BC7, BC25, BO10 and BTd43) selected as above described were tested in Petri dishes containing Potato Dextrose Agar (PDA). To this aim, a drop $(5 \mu \mathrm{l})$ of $V$. dahliae conidial suspension in sterile distilled water was placed in the centre of the plate and, subsequently, a drop $(5 \mu \mathrm{l})$ of each bacterial strain in PBS containing $1 \times 10^{9}$ cells was placed at $30 \mathrm{~mm}$ from $V$. dahliae microconidial drop. Plates were incubated at $28^{\circ} \mathrm{C}$ and, after different time periods $(3,5,7,10$, and 16 days), the radius of the developed fungal colony was measured in each plate (Vitullo et al. 2012).

The bacterial strains BO7 of B. amyloliquefaciens and BTd1 of $B$. cepacia proved to be the most effective antagonists in assays on agar media, and were further tested in liquid medium assays carried out in 96-well microtiter plates according to Skrobek et al. (2005). Using the same methodology, assays were performed to assess the inhibitory activity (IA) in vitro of selected OAWEs. In the multiwell plate, each sample (total volume $200 \mu \mathrm{l}$ ) contained $95 \mu \mathrm{l}$ of PDB and $10 \mu \mathrm{l}$ of $V$. dahliae suspension $\left(10^{5}\right.$ conidia $\left.\mathrm{ml}^{-1}\right)+95 \mu \mathrm{l}$ cell-free bacterial culture supernatant or $95 \mu \mathrm{l}$ of OAWEs. Plates were incubated at $28^{\circ} \mathrm{C}$ on a rotary shaker $(200 \mathrm{rpm})$ and for different lengths of time $(24,48$ and $72 \mathrm{~h})$, the increase in fungal biomass was determined spectrophotometrically $(595 \mathrm{~nm})$ using a Microplate Reader (mod. 550, Bio-Rad). Uninoculated medium was used as a blank. The percentage of inhibitory activity was calculated using the formula: $\mathrm{IA}=[(C-T) / C] \times 100$, where $C$ corresponds to the absorption of the untreated control and $T$ corresponds to the absorption in the presence of the bacterial filtrate.

During the experiments, microscopic observations were performed on $V$. dahliae conidia and mycelium subjected to different treatments. Samples, with different incubation times and either with crude bacterial culture filtrate or with OAWEs, were transferred from the microwells to a microcentrifuge tube. After centrifugation at 4,000 rpm for $5 \mathrm{~min}$, the pellet was re-suspended in glycerol-PBS (1:1 v/v) (Schoffelmeer et al. 1999), observed under interference contrast microscopy (DICM) (mod. BH2, Olympus, Japan), and images were recorded with a digital camera (mod. C5050, Olympus, Japan).

Growth chamber and nursery suppressive experiments

Following the in vitro assays, the suppressive effect of OMW-Ms against $V$. dahliae was assessed in plastic pot (3.5 L) experiments under both controlled (2008) and commercial olive nursery (2009 and 2010) conditions.

The experimental OMW-Ms were tested in a mixture at $15 \%$ (v/v) with "Sonnoli", a standard plant growing matrix commonly used in olive nursery in Italy (Sonnoli: $60 \%$ peat and $40 \%$ pumice powder, $2 \mathrm{~kg} \mathrm{~m}^{-3}$ Osmocote 14-13-13 NPK). In all experiments a randomized block design was used and each treatment included a total of 24 pots with four replications (blocks) of six pots per treatment.

Experiments under controlled conditions (12,000 lux, $25{ }^{\circ} \mathrm{C}$ temperature and 70-80\% RH) were carried out in a growth-chamber (mod. PE 2424 UY-LX Angelantoni, Italy). Trials were performed on potted mixtures without plants in the following treatments: (a) $15 \%$ OMWM1 + $85 \%$ Sonnoli; (b) $15 \%$ OMW-M2 + $85 \%$ Sonnoli; (c) $100 \%$ Sonnoli CC (contaminated control) + TV1; (d) $100 \%$ Sonnoli CC + BO7; (e) $100 \%$ Sonnoli CC + BTd1; (f) $100 \%$ Sonnoli CC; (g) $100 \%$ Sonnoli UC (uncontaminated control).

Bacterial strains $\mathrm{BO} 7$ or BTd1 were applied to the mixture by spraying them with a bacterial suspension at $1 \times 10^{9} \mathrm{cfu} \mathrm{ml}^{-1}$. Except for the treatment $(\mathrm{g})$, the substrates were artificially contaminated with a density of 50 MS of $V$. dahliae per gram.

Olive plants cv. Leccino from 2-year-rooted cuttings were used in the nursery experiments. Immediately before planting into plastic pots, the plants were wounded by removing a few millimetres of the apical roots. In order to reduce the stress of transplanting, plants were kept for 3 weeks in a shaded greenhouse $\left(22-26{ }^{\circ} \mathrm{C} \mathrm{T}\right.$ and $80-95 \%$ $\mathrm{RH})$ and then transferred to an outdoor section of the nursery. Trials were conducted from May to August and climatic parameters (temperature and relative humidity) were constantly monitored using a Thermo-Hygrometer (Mod. 1750-2/QM, Salmoiraghi, Italy). In the nursery, the 
following treatments were tested: (a) $15 \%$ OMW$\mathrm{M} 1+85 \%$ Sonnoli (standard growing matrix); (b) $15 \%$ OMW-M1 + 85\% Sonnoli + BO7; (c) $15 \%$ OMWM1 + $85 \%$ Sonnoli + BTd1; (d) $100 \%$ Sonnoli CC (contaminated control) + TV1; (e) $100 \%$ Sonnoli CC + BO7; (f) $100 \%$ Sonnoli CC + BTd1; (g) $100 \%$ Sonnoli CC; (h) $100 \%$ Sonnoli UC (uncontaminated control). Except for the treatment (h), the substrates were artificially contaminated with a density of $50 \mathrm{MS}$ of $V$. dahliae per gram.

Monitoring of $V$. dahliae MS in the rhizosphere

During both growth-chamber and nursery experiments, the density of $V$. dahliae MS was periodically quantified in samples of mixture taken from each pot at 30-day intervals. From each randomized block and for each treatment (6 pots), 6 subsamples of 5-g soil (a subsample per each pot) were mixed to obtain a sample of $30 \mathrm{~g}$. This sample was split into two subsamples of $15 \mathrm{~g}$. A subsample was examined by semi-selective medium in blind trial experiments, whereas the other subsample was analyzed by a molecular method based on the real-time scorpion polymerase chain reaction (PCR) technique.

Assays on semi-selective medium Each sample mixture $(15 \mathrm{~g})$ was suspended in $100 \mathrm{ml}$ of sterile distilled water and after $1 \mathrm{~h}$ of agitation at $270 \mathrm{rpm}$ on a rotary shaker; the suspension was filtered through two overlapping sieves having a mesh size of 150 and $32 \mu \mathrm{m}$, respectively. The material recovered on the lower sieve $(32 \mu \mathrm{m})$ was collected in a flask and re-suspended in $100 \mathrm{ml}$ of sterile distilled water, then aliquots of $2 \mathrm{ml}$ were distributed in Petri dishes containing the $V$. dahliae semi-selective medium reported by Huisman (1988). After 15 days of incubation at $24{ }^{\circ} \mathrm{C}$ in the dark, plates were washed under a gentle flow of tap water and then incubated for an additional time of 15 days at the same temperature. Colonies (each corresponding to a MS) grown on the medium of each plate were visualized and enumerated under a stereo-microscope (mod. SZH10, Olympus, Japan) at $20 \times$ magnification. The amount of $V$. dahliae MS was quantified and expressed as the number of MS per gram of dry soil mixtures.

Real-time scorpion PCR V. dahliae MS were quantified using the specific real-time scorpion PCR method as previously reported (Nigro et al. 2002; Schena et al. 2004). Briefly, total genomic DNA was extracted from each sample mixture using the protocol described by Cullen et al. (2001) with some modifications. The mixture samples were dried at room temperature for 10 days, crumbled, mixed and sieved with a 2-mm mesh. For each sample, DNA extraction was performed in triplicate. Soil mixture $(0.5 \mathrm{~g})$ was suspended in $1,000 \mu \mathrm{l}$ of extraction buffer $\left(0.12 \mathrm{M} \mathrm{Na}_{2} \mathrm{HPO}_{4}, 1.5 \mathrm{M} \mathrm{NaCl}\right.$, $2 \%$ CTAB) in the presence of two 5-mm stainless steel ball bearings and $0.5-\mathrm{g}$ acid-washed glass beads $(425-600 \mu \mathrm{m}$ diameter). The extraction mixture was homogenized in a FastPrep apparatus (Thermo Savant, Holbrook, NY, USA) to dislodge DNA from the substrate at speed level 4 for $30 \mathrm{~s}$ and then centrifuged at $14,000 \mathrm{rpm}$ for $5 \mathrm{~min}$ at $4{ }^{\circ} \mathrm{C}$. The upper phase was extracted with $750 \mu \mathrm{l}$ of chloroform, precipitated with two volumes of isopropanol, washed with $70 \%$ cold ethanol, dried and re-suspended in $50 \mu \mathrm{l}$ of sterile distilled water. Before amplification, DNA was purified with Sepharose CL-6B (Amersham Pharmacia Biotech Europe GmbH, Freiburg, Germany) in a spin column (Schena et al. 2002).

Two microliter of purified genomic DNA was amplified using a real-time nested-PCR protocol as previously reported (Nigro et al. 2002). Briefly, in the first step, amplifications were carried out with primers Ver2-Ver3; in nested PCR, $1 \mu \mathrm{l}$ of amplified product obtained was utilized as the template for the primer pair Vd7b-Vd10. The Vd7b primer was modified according to Whitcombe et al. (1999) to obtain a Scorpion primer for amplicon detection by fluorescence emitted from a fluorophore through a selfprobing reaction (Oswell Research Products Ltd., Southampton, UK). Amplification was conducted in sealed tubes in a 96-well microtiter plate (Bio-Rad, Hercules, CA, USA) and fluorescence was monitored using a spectrofluorometric thermal cycler (iCycler Thermal Cycler, Bio-Rad, Hercules, CA, USA) for real-time data collection during annealing-extension. Relative normalized fluorescence $(\Delta \mathrm{Rn})$ was plotted and utilized to calculate the average background fluorescence emission in the initial PCR cycles before fluorescence increased. Threshold fluorescence intensity was established at tenfold above the standard deviation in the initial PCR cycles, and any sample that reached a fluorescence value exceeding the fluorescence threshold value was considered positive (Schena et al. 2004). DNA from pure cultures of $V$. dahliae was used as a positive control, whereas water (no template DNA in PCR) was used as a negative control.

\section{Bacterial population in pot mixtures}

During the nursery experiments, the total bacterial population in the mixtures subjected to different treatments was periodically evaluated at the inoculation time (T0), and after 30 (T30), 60 (T60) and 90 (T90) days. Hence, $1 \mathrm{~g}$ of mixture taken from each pot was suspended in $9 \mathrm{ml}$ of phosphate buffer $\left(\mathrm{NaCl} 0.14 \mathrm{M}, \mathrm{KCl} 2.7 \mathrm{mM}, \mathrm{Na}_{2} \mathrm{H}-\right.$ $\mathrm{PO}_{4} \times 2 \mathrm{H}_{2} \mathrm{O} 8.1 \mathrm{mM}, \mathrm{KH}_{2} \mathrm{PO}_{4} 1.8 \mathrm{mM}, \mathrm{pH}$ 7.4) and kept at $28{ }^{\circ} \mathrm{C}$ on a rotary shaker $(150 \mathrm{rpm})$ for $30 \mathrm{~min}$. Suspensions were filtered through four layers of sterile cheesecloth, mixture water extracts were serially diluted $\left(10^{-5}\right.$, $10^{-6}$ and $10^{-7}$ ), and $100 \mathrm{ml}$ of each diluted suspension was plated in Petri dishes containing nutrient agar (NA). Plates were incubated at $28{ }^{\circ} \mathrm{C}$ for 2 days and bacterial colonies were enumerated and expressed as $\mathrm{cfu}^{-1}$ of mixtures. 
Statistical analysis

All experiments were performed twice with similar results. The tests in the growth chamber and in the nursery were repeated in different years. Homogeneity of variance for repetitions of each experiment was evaluated and data from separate experiments with homogeneous variances were pooled.

Data were submitted to variance analysis (ANOVA) using the SPSS software (version 16.0 for Windows, SPSS Inc. Chicago, IL, USA) and means were compared by the Tukey's test. The percentages were converted to Bliss angular values (arcsine square root) before analysis of variance.

\section{Results and discussion}

Characteristics of organic amendments

The main physical-chemical characteristics of the amendments OMW-M1 and OMW-M2 used in this study are summarized in Table 1.

Differences can be attributed to the diversity of ingredients used and the maturation techniques carried out. The addition of sewage sludge in OMW-M2 resulted in higher EC and $\mathrm{P}_{2} \mathrm{O}_{5}$, 4.8- and 3.4-fold higher than OMW-M1, respectively. On the other hand, the higher percentage of humid olive husk used in OMW-M1 led to higher TP, Fat, K and Mg, since humid husk is a rich source of these elements (Altieri and Esposito 2008). The addition of waste wool, rich in organic nitrogen, determined a lower $\mathrm{C} / \mathrm{N}$ ratio in OMW-M1.

Both amendments showed sub-alkaline $\mathrm{pH}$, typical of stable and mature compost (Alfano et al. 2008, 2009a; Altieri and Esposito 2008; Ranalli et al. 2001). Both maturation techniques led to well-humified amendments, characterized by low phytotoxicity. Furthermore, humic carbon and GI values were much higher than the minimum targets (humic carbon $=7 \%$, GI $=60 \%$ ) set as standards for composts derived from aerated systems by Italian law (DL 75/2010).

In vitro activity of biocontrol agents (BCAs)

and organic amendments water extracts (OAWEs)

against $V$. dahliae

Some representative bacterial strains isolated from suppressive soils were tested in dual culture assays in vitro against $V$. dahliae. All the bacteria tested (12 isolates) evidenced an inhibition zone against the pathogen growth which continued to increase up to 16 days from the beginning of the experiment. At this time, in particular, the potential antagonists showed values of inhibitory activity ranging from $23 \%$ (strain BC7) to $60 \%$ (strains BO7 and BO10) (Fig. 1).

Among the most effective antagonists, the bacterial isolates BO7 and Btd1, identified as Bacillus amyloliquefaciens
Table 1 The main characteristics of the organic amendments OMWM1 (aerobic static storage) and OMW-M2 (composted), used in the suppressive experiments against $V$. dahliae

\begin{tabular}{lcc}
\hline Parameter $^{\mathrm{a}}$ & OMW-M1 & OMW-M2 \\
\hline Moisture (\%) & $51.0 \pm 3.5$ & $44.1 \pm 1.2$ \\
$\mathrm{pH}$ & $6.9 \pm 0.2$ & $7.5 \pm 0.1$ \\
Electrical conductivity $\left(\mathrm{mS} \mathrm{cm}^{-1}\right)$ & $1.35 \pm 0.35$ & $6.46 \pm 0.20$ \\
Ash $(\%)$ & $9.90 \pm 1.41$ & $7.55 \pm 0.60$ \\
Cation exch. capacity $\left(\mathrm{cmol}_{(+)} \mathrm{kg}^{-1}\right)$ & $56.0 \pm 2.0$ & $63.7 \pm 1.2$ \\
Total organic carbon $(\%)$ & $42.3 \pm 1.8$ & $43.7 \pm 0.8$ \\
$\mathrm{C} / \mathrm{N}$ & 19.5 & 36.4 \\
Humic carbon $(\%)$ & $15.9 \pm 0.3$ & $24.4 \pm 0.4$ \\
Fat $(\%)$ & $4.90 \pm 0.7$ & $2.23 \pm 0.5$ \\
Total polyphenols $\left(\mathrm{g} \mathrm{kg}{ }^{-1}\right.$ gallic acid) & $0.27 \pm 0.04$ & $0.12 \pm 0.02$ \\
Germination index $(\%)$ & 71 & 88 \\
Total nitrogen $(\%)$ & $2.17 \pm 0.18$ & $1.20 \pm 0.10$ \\
$\mathrm{P}_{2} \mathrm{O}_{5}(\%)$ & $0.16 \pm 0.05$ & $0.55 \pm 0.10$ \\
$\mathrm{~K}_{2} \mathrm{O}(\%)$ & $2.6 \pm 0.2$ & $1.4 \pm 0.1$ \\
$\mathrm{Ca}(\%)$ & $1.12 \pm 0.15$ & $1.02 \pm 0.10$ \\
$\left.\mathrm{Mg}_{(\mathrm{mg} \mathrm{kg}}{ }^{-1}\right)$ & $2903 \pm 58$ & $1307 \pm 37$ \\
\hline
\end{tabular}

${ }^{a}$ Data reported are average values \pm standard deviation calculated from three replicate assessments

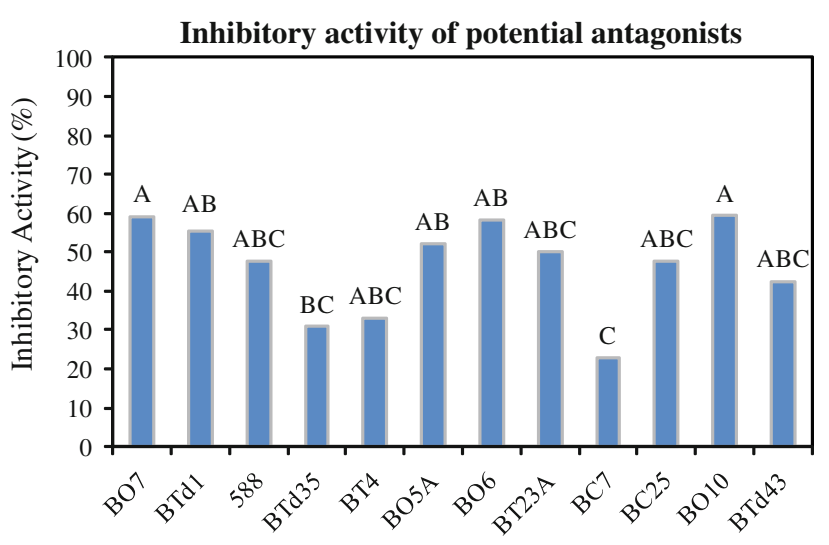

Fig. 1 Inhibitory activity (IA, \%) of 12 selected bacterial strains against Verticillium dahliae in in vitro dual culture assays. Fungal growth was determined by direct measurement of colony diameter after 16 days of incubation at $28{ }^{\circ} \mathrm{C}$. IA was calculated as percentage of radial fungal growth reduction compared to the control (fungal growth on solid media without bacteria). Values marked by common letters are not statistically different at $P=0.01$ according to Tukey's test

$(\mathrm{Gram}+)$ and Burkholderia cepacia (Gram-), respectively, were used in the following tests in vitro and in vivo. This choice was also supported by previous studies where these two antagonists were tested as biocontrol agents against other fungal pathogens and characterized by their mechanisms of action (i.e., production of antifungal metabolites) (De Curtis et al. 2010; Vitullo et al. 2012).

The results of in vitro tests against $V$. dahliae performed in multiwell plates using both bacterial crude filtrates and water extracts from OMW-M1 and OMW-M2 are reported in 


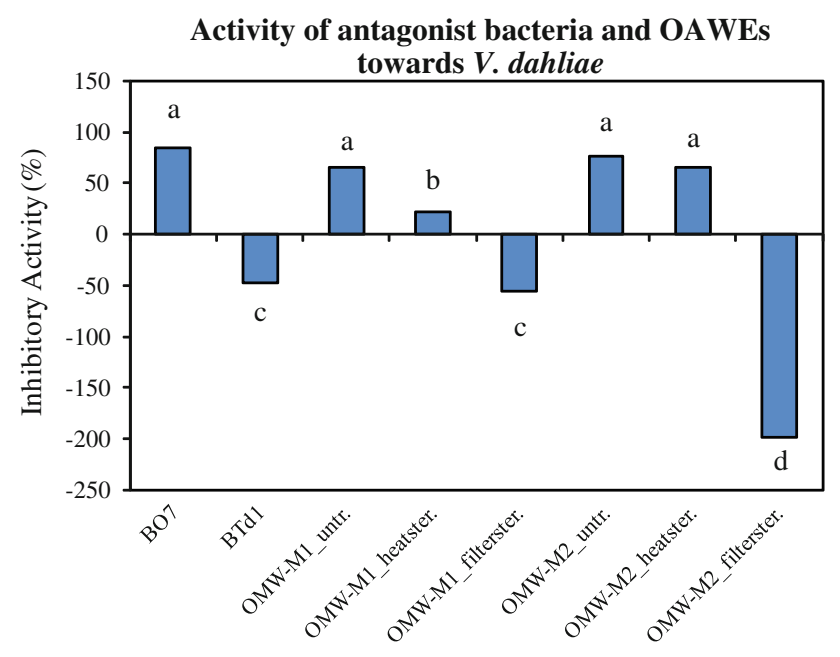

Fig. 2 Inhibitory activity (IA, \%) of Bacillus amyloliquefaciens (BO7) and Burkholderia cepacia (BTd1) crude culture filtrates and organic amendments (OMW-M1 and OMW-M2) water extracts (OAWEs) against $V$. dahliae. Fungal growth was determined spectrophotometrically by measuring absorption at $595 \mathrm{~nm}$. IA was calculated as percentage of fungal biomass reduction compared to the control (fungal growth on liquid media without culture filtrate). _untr. $=$ untreated OAWEs; heatster. = OAWEs boiled at $100^{\circ} \mathrm{C}$ for 10 min.;_filterster. = OAWEs sterilized by filtration at $0.22 \mu \mathrm{m}$. Values marked by common letters are not statistically different at $P=0.05$ according to Tukey's test

Fig. 2. With respect to the untreated control, the crude filtrate of the biocontrol bacteria $\mathrm{BO} 7$ inhibited about $85 \%$ of the growth of $V$. dahliae mycelium, whereas the crude filtrate of Btd1 was not only ineffective, but even stimulated by about $50 \%$ the growth of the pathogen. These results confirm the authors' previous findings (Vitullo et al. 2008) where filtrates of isolate $\mathrm{BO} 7$ were more effective in inhibiting fungal pathogens than filtrates of isolate BTd1. This result is probably due to the capacity of $\mathrm{BO} 7$ to produce high amounts of antifungal lipopeptides of the surfactin family displaying a strong inhibitory activity in vitro (Vitullo et al. 2012).

The untreated water extracts of OMW-M1 and OMW-M2 inhibited the pathogen growth by about 65 and $76 \%$, respectively. As water extract of OMW-M1 was boiled at $100{ }^{\circ} \mathrm{C}$ its inhibitory activity was reduced to a level similar to the control, whereas the boiling did not influence the activity of OMW-M2. Conversely, the pre-sterilization by filtration at $0.22 \mu \mathrm{m}$ not only induced a consistent loss of inhibitory activity in water extracts of both matrices (OMWM1 and OMW-M2), but even stimulated the fungal growth.

The activity displayed by water extracts of OMW-Ms was also evidenced by microscopic observations carried out during the assays. In particular, images reported in Fig. 3 for OMW-M1 evidenced the abundant presence of $V$. dahliae mycelium in the control (Fig. 3a), a small quantity of fungal mycelium together with an abundant quantity of bacterial cells in untreated OMW-M1 water extract (Fig. 3b), the presence of both bacterial microorganisms and fungal mycelium in boiled OMW-M1 water extract (Fig. 3c) as well as the presence of abundant fungal mycelium and the absence of bacterial microorganisms in filter sterilized OMW-M1 water extract (Fig. 3d).

The reduction or disappearance of antifungal activity in the sterilized water extract of OMW-Ms (Figs. 2 and 3a) clearly corroborates the involvement of the beneficial indigenous antagonist microflora normally contained in these organic matrices (Alfano et al. 2009b) and agrees with previous research demonstrating loss or reduction in compost suppressive activity following its sterilization or pasteurisation before use (Lima et al. 2008; Malandraki et al. 2008; Yogev et al. 2009).

The high inhibitory activity exerted by OMW-M2 water extract, even after boiling, could be due to thermostable antifungal compounds from vegetal origin, i.e., residual phenolics and fatty acids (Alfano et al. 2009b; Lima et al. 2008).

Growth chamber and nursery suppressive experiments

The results of suppressive experiments carried out under controlled conditions (growth chamber), with contaminated organic matrices dispensed in plant-less plastic pots, are reported in Fig. 4. Data of MS monitoring on semi-selective medium (Fig. 4a, b) showed that in samples of soil taken soon after the application of treatment (T0), around $53 \mathrm{MS} \mathrm{g}^{-1}$ of soil were found in the control mixture artificially contaminated with $V$. dahliae (CC: contaminated control). At that sampling, only the soil mixtures treated with the biocontrol bacteria (BO7 or BTd1) or biofungicide TV1 showed a consistent lower (from 75 to $90 \%$ less) MS density. OMW-M1 and OMW-M2, applied at $15 \% \mathrm{v} / \mathrm{v}$ in mixture with the standard substrate (Sonnoli) evidenced a strong suppressive activity on the survival of $V$. dahliae MS only in the soil samples taken at 90 days. At this time, about $50 \mathrm{MS} \mathrm{g}^{-1}$ of soil were found in the CC, whereas OMW-M1 and OMW-M2 reduced MS density by $100 \%\left(0 \mathrm{MS} \mathrm{g}^{-1}\right)$ and $70 \%\left(13 \mathrm{MS} \mathrm{g}^{-1}\right)$, respectively. The suppressive activity of OMW-M1 was comparable with the activity of the biocontrol bacteria $\mathrm{BO} 7$ and BTd1 as well as the commercial biofungicide TV1 (Trichoderma asperellum). No MS were found in the uncontaminated soil mixture. Data assessed by semi-selective medium (SPT) (Fig. 4a, b) are substantially in accordance with those obtained in "blind trial" assessments using the real-time scorpion PCR (Fig. 4c, d).

As a consequence of the results obtained in the growth chamber experiment, OWM-M1 and the biocontrol bacteria BO7 and BTd1, alone or in combination, were further tested on young olive plants kept in a commercial olive nursery. The results of these experiments are reported in Fig. 5. On semi-selective media (Fig. 5a, b), at the first sampling 
Fig. 3 Fungal mycelium of $V$. dahliae observed under interferential contrast microscopy (ICM) after $48 \mathrm{~h}$ of co-incubation with water extracts of OMW-M1 in the multiwell plate assay of Fig. 2. Control PDB media + water $1: 1 \mathrm{v} / \mathrm{v}, O M W-M 1-W E$ untreated water extract of OMW-M1, OMW-M1-WE heatster. OMW-M1 water extract boiled at $100{ }^{\circ} \mathrm{C}$ for $10 \mathrm{~min}, O M W-M 1-W E$ filterster. OMW-M1 water extract filtersterilized

\section{ICM images of OAWEs against $V$.dahliae}

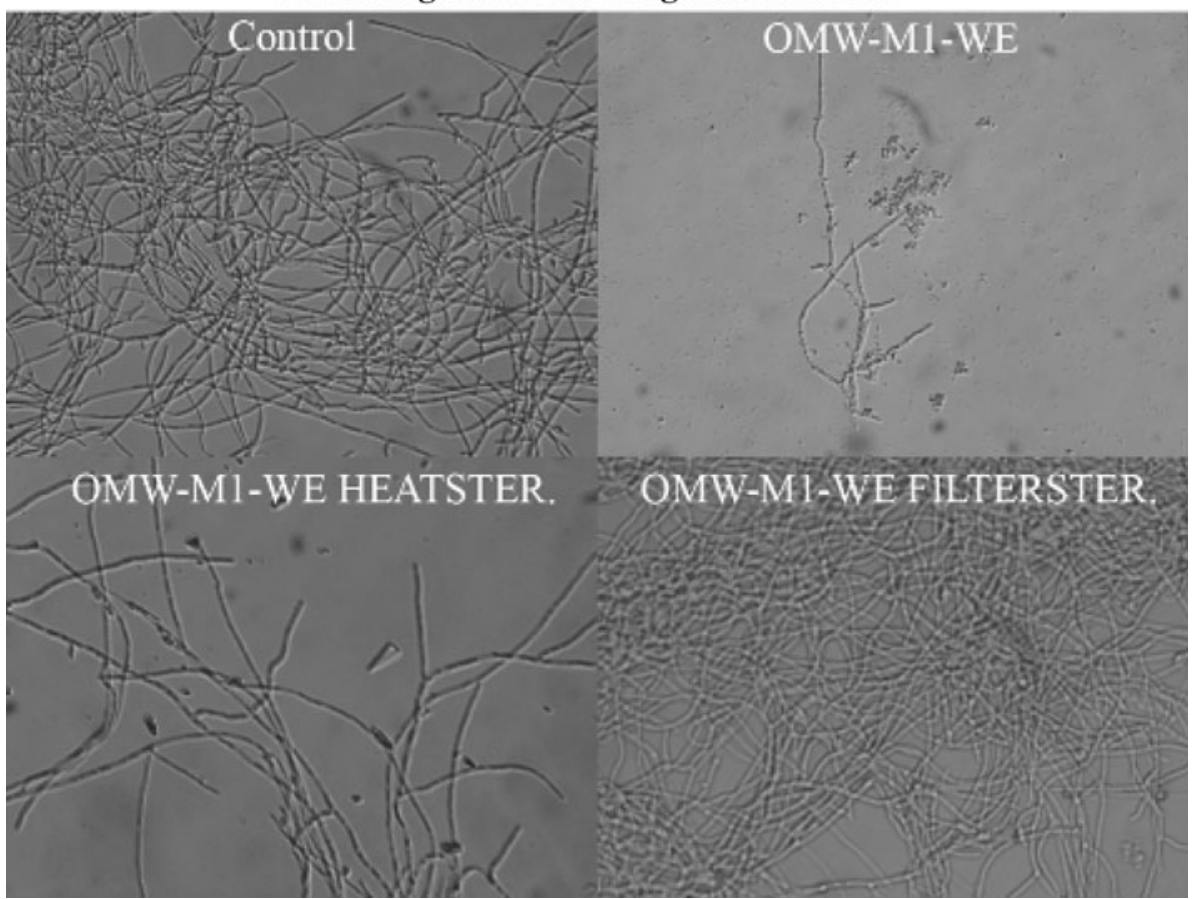

Monitoring of $V$. dahliae microsclerotia in growth chamber experiments
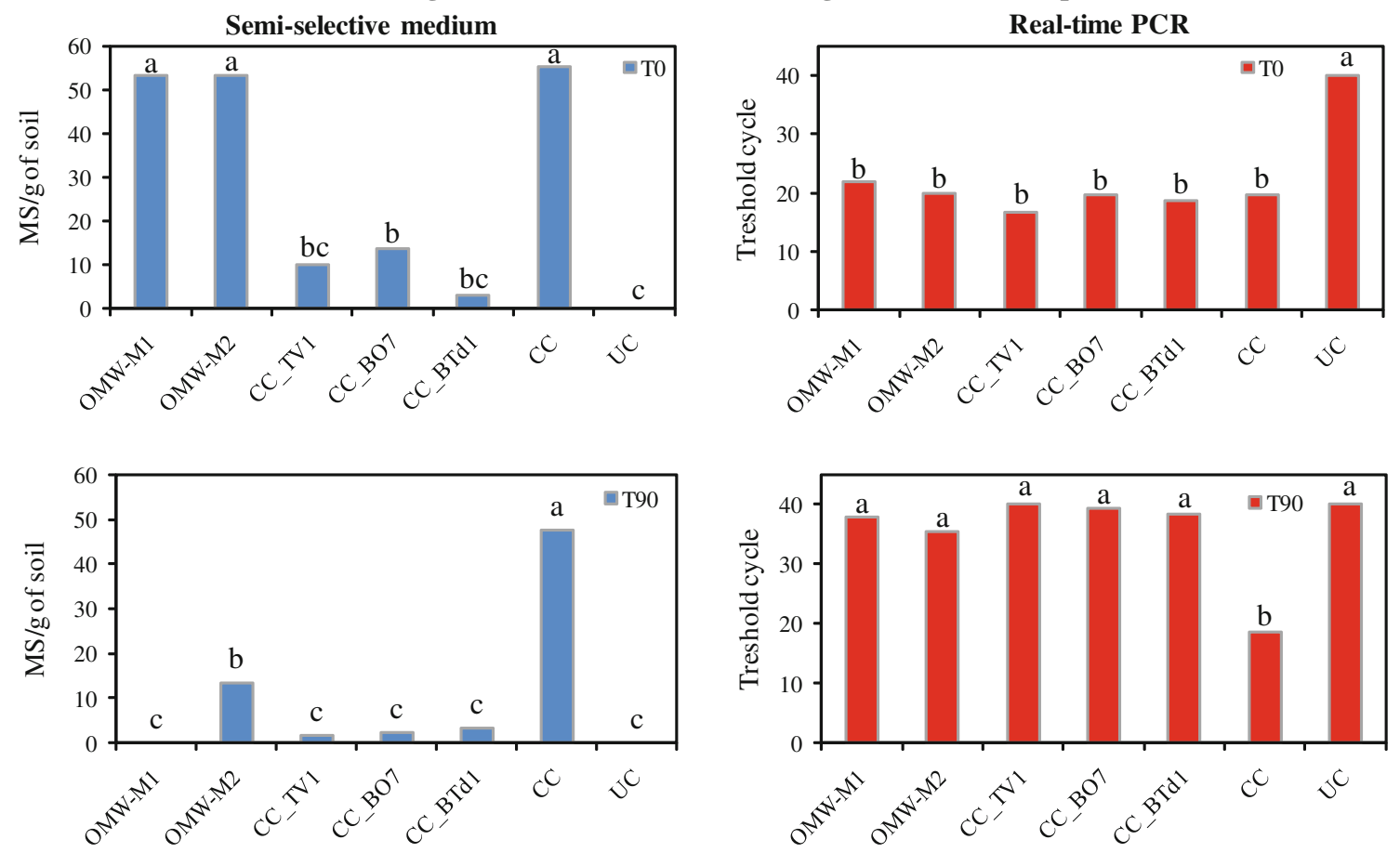

Fig. 4 Density of $V$. dahliae microsclerotia (MS) recovered at inoculation time (T0) and after 90 days (T90) in a standard nursery matrix amended with or without $15 \%$ of stabilized Olive Mill Waste Mixtures (OMW-M1 or OMW-M2) and antagonist microorganisms $(\mathrm{BO} 7=$ B. amyloliquefaciens or $\mathrm{BTd} 1=$ B. cepacia $)$ in experiments carried out in the growth chamber. All mixtures, except for "UC", were contaminated with $50 \mathrm{~V}$. dahliae MS $\mathrm{g}^{-1}$. CC Contaminated

control, UC uncontaminated control. $V$. dahliae MS were assessed by both semi-selective medium and real time Scorpion PCR. The commercial biofungicide TV1, based on the biocontrol agent Trichoderma asperellum, was used as a control. Values marked by common letters are not statistically different at $P=0.05$ according to Tukey's test 
(Fig. 5a), the contaminated control (CC) evidenced a density of $77 \mathrm{MS} \mathrm{g}^{-1}$ of mixture. At this sampling, contrarily to assays conducted in the growth chamber, a drastic reduction of MS density was observed for OWM-M1 (25.5 MS $\mathrm{g}^{-1}$ ). A higher reduction of MS density was observed when OWM-M1 was combined with the biocontrol bacteria BO7 (5.5 $\mathrm{MS} \mathrm{g}^{-1}$ ) or BTd1 (10.5 MS g $\mathrm{g}^{-1}$ ).

The suppressive activity of OMW-M1, alone or combined with the biocontrol bacteria BO7 or BTd1, was even better than the activity generated by the commercial biofungicide TV1 (44.5 $\mathrm{MS} \mathrm{g}^{-1}$ of soil). However, BO7 and BTd1 when applied alone were ineffective, showing a density of MS even higher than that of the control ( $>100 \mathrm{MS} \mathrm{g}^{-1}$ of soil).

The samples taken after 90 days from the beginning of the experiments (Fig. 5b) showed a drastic reduction of MS density in the mixture of all treatments. However, some differences that were still evident at that time indicate OWMM1 alone and OWM-M1 combined with BO7 or BTd1 as the best treatments (no MS found in these treatments in comparison with about $5 \mathrm{MS} \mathrm{g}^{-1}$ recovered in the $\mathrm{CC}$ ).
In nursery experiments, the suppressive activity of the amendment (OMW-M1), applied alone or in combination with the biocontrol bacteria, was already evident from the first sampling (T0), whereas biocontrol agents were ineffective at that stage. After 90 days, differences between all treatments were reduced or disappeared because of a general reduction in MS density in all the treatments (Fig. 5). Conversely, in growth chamber assays (Fig. 4), the amendments (OMW-M1 and OMW-M2) showed no suppressive activity at $\mathrm{T} 0$, while they evidenced strong activity after 90 days, when the density of $V$. dahliae MS was still high in the contaminated control. Biocontrol agents applied alone displayed a high level of antagonist activity. As is known (Alfano et al. 2009a, b), the variability of outcomes of experiments performed at different periods of time may be due to varying biotic and abiotic factors that can affect the performance of amendments differently. Similarly, the antagonist activity of biocontrol agents can be negatively affected by variable climatic conditions (Pullman et al. 1981), i.e., in the present research for experiments conducted
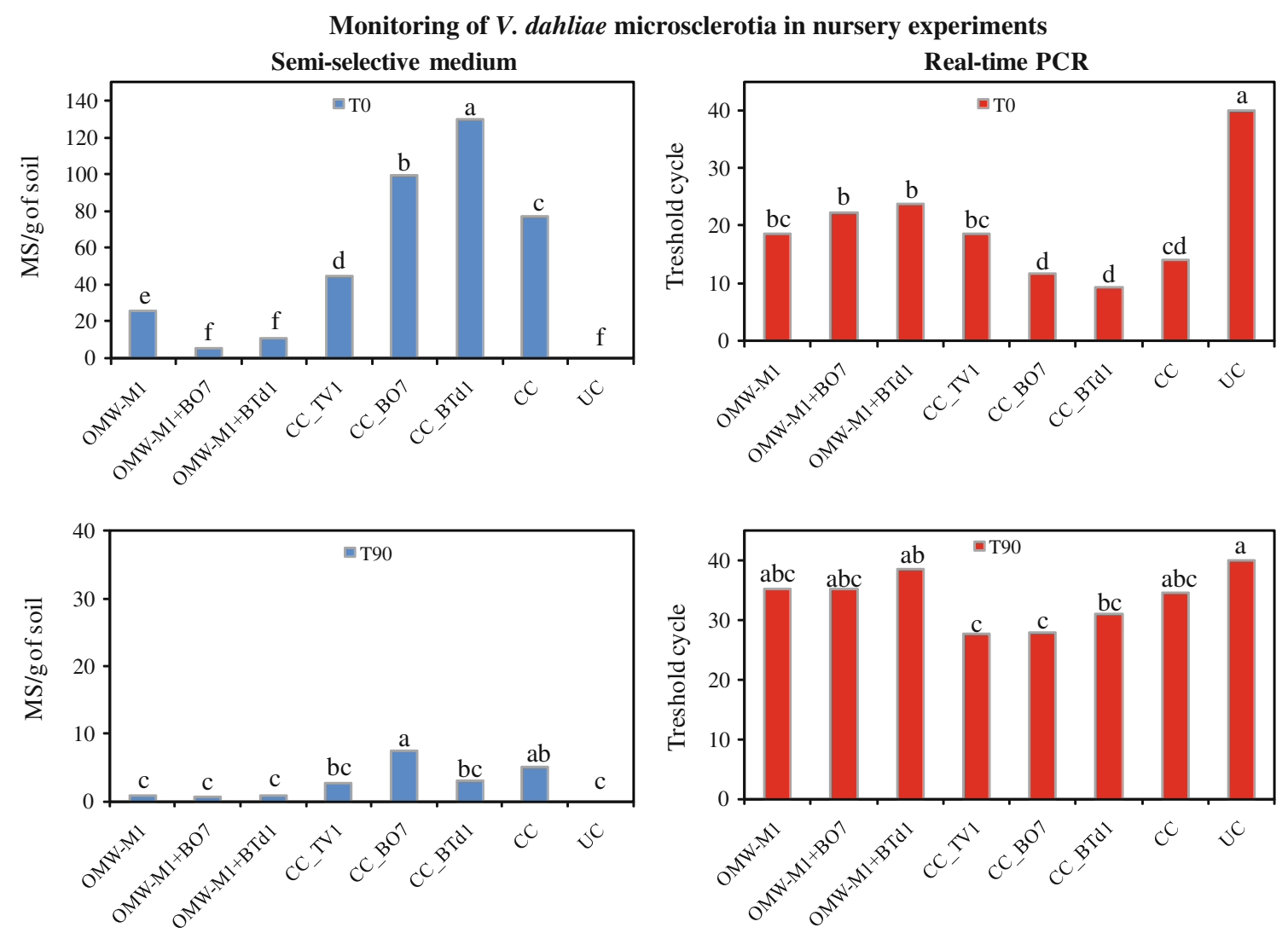

Fig. 5 Density of $V$. dahliae microsclerotia (MS) recorded at inoculation time (TO) and after 90 days (T9O) in a standard nursery matrix amended with or without $15 \%$ OMW-M1 (stabilized olive mill waste mixture) and the antagonist microorganisms $(\mathrm{BO} 7=B$. amyloliquefaciens and $\mathrm{BTd} 1=B$. cepacia $)$ in experiments carried out in a commercial olive nursery. All mixtures, except for "UC", were contaminated by $50 \mathrm{~V}$. dahliae $\mathrm{MS} \mathrm{g}^{-1}$.

$C C$ contaminated control, $U C$ uncontaminated control. The commercial biofungicide TV1, based on the biocontrol agent $T$. asperellum, was used as a control. $V$. dahliae MS were assessed by both semiselective medium $(\mathbf{a}, \mathbf{b})$ and real-time scorpion PCR $(\mathbf{c}, \mathbf{d})$. Values marked with common letters are not statistically different at $P=0.05$ according to Tukey's test 
in the olive nursery, where summer environmental temperatures, in particular, were frequently above $30{ }^{\circ} \mathrm{C}$ (data not shown), whereas in growth chamber assays climatic conditions (T, UR and photoperiod) were stable.

Apart from the possible variability among experiments, combined applications of amendment OMW-M1 and biocontrol bacteria $\mathrm{BO} 7$ or BTd1 generally seem to be a valuable control strategy to reduce the amount of $V$. dahliae inoculum in the rhizosphere and to reduce risks for Verticillium wilt in olive plants as demonstrated by the authors' assays conducted in the olive nursery.

No MS were found in the uncontaminated soil mixtures either in the nursery experiments or in the previous assays conducted in the growth chamber. Moreover, the data regarding the monitoring of $V$. dahliae MS with the semiselective medium (SPT) concurred with those obtained in "blind trial" assessments using the real-time scorpion PCR assay. These results also confirm the authors' previous research where the two monitoring methods for $V$. dahliae were compared (Lima et al. 2007).

The obtained positive results are in agreement with other studies which have evidenced that suppressive biomasses can effectively control various plant pathogens (e.g., Botrytis cinerea, Fusarium oxysporum, Phytophthora capsici, P. nicotianae, Pythium ultimum, Rhizoctonia solani, Sclerotinia minor) responsible for severe plant diseases (Noble and Coventry 2005; Ntougias et al. 2008; Pane et al. 2011; Saadi et al. 2010). The mechanisms of suppressiveness of OMW-M1 and OMW-M2, as reported for other similar matrices, seem mainly due to the antagonism exerted by their beneficial microbial population. The key factors of stabilized biomass suppressiveness seem to be related to their microbial status as well as to the rate of activity and quality of the microbial community inhabiting compost and other biomasses. Species of Pseudomonas, Klebsiella, Enterobacter, Bacillus and Streptomyces, among bacteria, and Penicillium, Trichoderma and Gliocladium, among fungi, have been isolated from the compost as the main antagonist microorganisms involved in disease suppressiveness (Boulter et al. 2002; Nelson and Boehm 2002). In addition, suppressiveness of cured amendments may be partially due to inhibitory activity exerted by some residual antimicrobial compounds (fatty acids, polyphenolics, etc.) contained in such biomasses (Alfano et al. 2009b).

\section{Bacterial population in pot mixtures}

Dynamics of total bacterial population assessed in the rhizosphere of olive plants subjected to varying nursery treatments are reported in Fig. 6.

At the first sampling (T0), clear differences in total bacterial population were found among the different treatments applied. In particular, at $\mathrm{T} 0$ in the contaminated control (CC: unbacterized standard substrate), a bacterial population

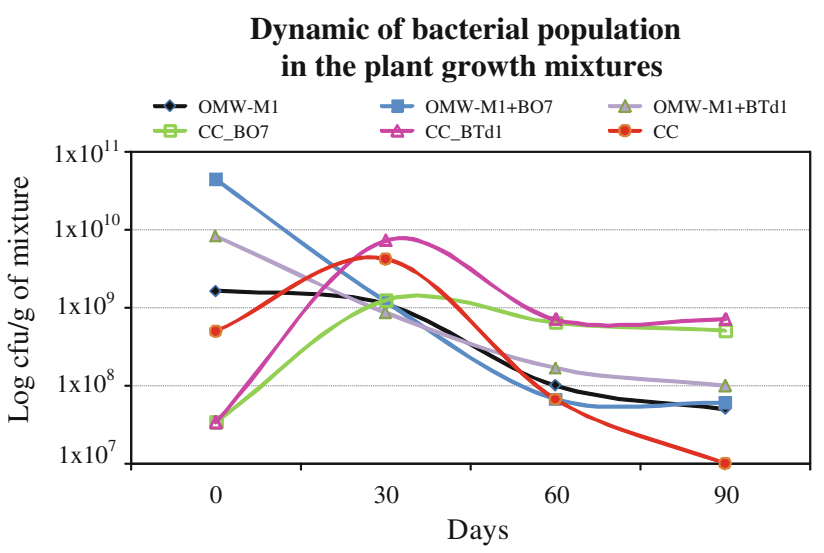

Fig. 6 Dynamics of total bacterial population in the rhizosphere of olive plants grown on a standard matrix amended with $15 \%$ of OMW-M1 (stabilized olive mill waste mixture) and the biocontrol bacteria $(\mathrm{BO} 7=$ B. amyloliquefaciens and $\mathrm{BTd} 1=$ B. cepacia $)$ alone or in combination

of $5 \times 10^{8} \mathrm{cfu} \mathrm{g}^{-1}$ was found, whereas consistently higher values were assessed in the combined treatment OMW-M1 + BO7 $\left(4.47 \times 10^{10}\right)$ and OMW-M1 + BTd1 $\left(8.33 \times 10^{9}\right)$. The treatment OMW-M1, BO7 and BTd1, applied separately, evidenced levels of population of $1.63 \times 10^{9}, 3.33 \times 10^{7}$ and $3.33 \times 10^{7} \mathrm{cfu} \mathrm{g}^{-1}$, respectively. From the first (T0) to the last sampling (T90), the bacterial population in the combined treatment OMWM1 + biocontrol bacteria decreased progressively reaching values around $1 \times 10^{8} \mathrm{cfu} \mathrm{g}^{-1}$ of mixture. By contrast, although the population in the standard substrate (Sonnoli) treated by the biocontrol bacteria $\mathrm{BO} 7$ and $\mathrm{BTd} 1$ showed low values at the first sampling $\left(3.33 \times 10^{7} \mathrm{cfu} \mathrm{g}^{-1}\right)$, it increased consistently from $\mathrm{T} 0$ to $\mathrm{T} 30$, reaching values that stabilized near $1 \times 10^{9}$ from T60 to T90. With respect to untreated control (CC), particularly in samples taken at 60 and 90 days, the levels of the total bacteria population were consistently higher in mixtures treated with the biocontrol bacteria $\mathrm{BO} 7$ and BTd1. Although higher than the control, the levels of total bacterial population in the combined treatments biocontrol bacteria + OMW-M1 were lower than in the mixture treated with biocontrol bacteria alone at the 90-day assessment.

Collectively, data on the bacterial population assessment evidenced that the application of the biocontrol bacteria $\mathrm{BO} 7$ and BTd 1 can modify the dynamics of total bacterial populations in different ways in the plant-growth mixture. The higher bacterial population recorded at the first assessment (T0) on combined treatment OMW-Ms + BO7 or BTd1, as compared with the very low population recorded at the same time for BO7 or BTd1 applied in the standard substrate, is probably due to the higher amount of organic compounds and nutrients contained in OMW-Ms with respect to the standard mixture. Subsequently (particularly after 60 days), the better colonization of the two introduced biocontrol bacteria in the standard mixture, with respect to the mixture amended with 
OMW-M1, is probably due to competition exerted by the rich indigenous microflora contained in OMW-M1 (Altieri et al. 2005), as well as to the possible increase in nutrients in the standard mixtures (i.e., increase in plant exudates, degradation of organic compounds, etc.). Furthermore, the data on the bacterial population (Fig. 6) are in full agreement with the data of $V$. dahliae MS density found in the mixture (Fig. 5). At T0, combined treatments based on OMW-Ms + BO7 or BTd1 exerted a consistently higher repressive activity against $V$. dahliae, whereas BO7 or BTd1 applied in the standard mixture did not. At the end of the experiments, (T90) OMW$\mathrm{Ms}+\mathrm{BO} 7$ or BTd1 and biocontrol bacteria, applied in standard mixtures, showed a similar or slightly different behaviour.

\section{Conclusion}

Composting and static storage are two reliable methods for recycling solid and sludge residues from two-phase olive oil mill industries. In conducted experiments, these processes resulted in obtaining two mature and stabilized matrices from olive mill residues (OMW-M1 and OMW-M2) with good agronomical characteristics and no phytotoxic effects. In addition to their positive agronomic properties, this research, carried out in different years in controlled conditions and in a commercial olive nursery, evidenced the strong suppressive activity of these innovative matrices against Verticillium dahliae. It was also demonstrated how the enrichment of organic amendments with biocontrol bacteria can be considered as a valuable strategy to further improve and optimize suppressiveness against soilborne pathogens.

Based on the positive results of the present research, it can be concluded that organic suppressive matrices from good quality cured olive mill by-products, together with selected biocontrol agents, have a high potential for application in organic and integrated agriculture systems, not only because of their positive agronomic properties, but also because of their suppressive activity against $V$. dahliae on olive plants and perhaps against other dangerous soilborne pathogens of other important vegetal crops.

\footnotetext{
Acknowledgments The research was supported by (a) the Italian "Ministero dell'Istruzione, dell'Università e della Ricerca", PRIN project, prot. 20089LSZ2A_003, "Studies on biocontrol agents and their biomolecules to optimize the suppressive activity of natural amendments against soilborne pathogens of horticultural crops", (b) the Italian "Ministero delle Risorse Agricole e Forestali", OLVIVA project "Qualificazione del vivaismo olivicolo: caratterizzazione varietale, sanitaria e innovazioni nella tecnica vivaistica" (L499/99 Programmi Interregionali), and (c) the European Union project "LIFE Environment TIRSAV PLUS: LIFE05 ENV/IT/000845". The authors are grateful to the Parco Scientifico "STAR" of Verona, and SETA SrL, Vigonza, Italy, for producing and supplying the composted substrate OMW-M2, and to the staff of the plant nursery "Verde Molise" Termoli, Italy, for technical assistance and equipment involved in the development of the suppressive experiments on olive plants. The authors also thank Janice Beccaria, from the Faculty of Foreign
}

Languages and Literature at the University of Salento, Lecce, Italy for her valuable assistance in the linguistic revision of the manuscript.

\section{References}

Alburquerque JA, Gonzálvez J, García D, Cegarra J (2007) Effects of a compost made from the solid by-product ("alperujo") of the two-phase centrifugation system for olive oil extraction and cotton gin waste on growth and nutrient content of ryegrass (Lolium perenne L.). Bioresource Technol 98(4):940-945

Alfano G, Belli C, Lustrato G, Ranalli G (2008) Pile composting of twophase centrifuged olive husks residues: technical solutions and quality of cured compost. Bioresource Technol 99(11):4694-4701

Alfano G, Lustrato G, Lima G, Vitullo D, Delfine S, Tognetti R, Ranalli G (2009a) Physico-Chemical, microbiological, agronomical, and phytopathological aspects in the recycling of olive waste composted residues. In: Martin-Gil J (ed) Dynamic soil dynamic plant, special issue 1, compost part II. Global Science Books, Isleworth, pp 64-72

Alfano G, Lustrato G, Lima G, Ranalli G (2009b) Present and future perspectives of olive residues composting in the Mediterranean basin (CompMed). Invited review. In: Martin-Gil J (ed) Dynamic soil dynamic plant, special Issue 1, Compost Part II. Global Science Books, Isleworth, pp 39-56

Altieri R, Esposito A (2008) Olive orchard amended with two experimental olive mill wastes mixtures: effects on soil organic carbon, plant growth and yield. Bioresource Technol 99(17):8390-8393

Altieri R, Esposito A (2010) Evaluation of the fertilizing effect of olive mill waste compost in short-term crops. Int Biodeter Biodegr 64(2):124-128

Altieri R, Pepi M, Esposito A, Fontanazza G (2005) Chemical and microbiological characterization of olive mill wastes based substrata produced by the (O.Mi.By.P.) technology (Olive Mill By-Products Processor) and their grounds amendment. In: Proceedings International Seminar: "The Role and Importance of Integrated Soil and Water Management for Orchards Development", Mosciano S. Angelo, Teramo, Italy, 9-10 May 2004, Fao Land Water Bull. n.10, 91-101

Berg G, Opelt K, Zachow C, Lottmann J, Gotz M, Costa R, Smalla K (2006) The rhizosphere effect on bacteria antagonistic towards the pathogenic fungus Verticillium differs depending on plant species and site. FEMS Microbiol Ecol 56(2):250-261

Borrero C, Ordovása J, Trillasb MI, Avilésa M (2006) Tomato Fusarium wilt suppressiveness. The relationship between the organic plant growth media and their microbial communities as characterised by Biolog ${ }^{\circledR}$. Soil Biol Biochem 38(7):1631-1637

Boulter JI, Trevors JT, Boland GJ (2002) Microbial studies of compost: bacterial identifications, and their potential for turfglass pathogens suppression. World J Microb Biot 18:661-671

Cullen DW, Lees AK, Toth IK, Duncan JM (2001) Conventional PCR and real-time quantitative PCR detection of Helminthosporium solani in soil and potato tubers. Eur J Plant Pathol 107:387-398

De Costa DM, Samarasinghe SST, Dias HRD, Dissanayake DMN (2008) Control of rice sheath blight by phyllosphere epiphytic microbial antagonists. Phytoparasitica 36(1):52-65

De Curtis F, Lima G, Vitullo D, De Cicco V (2010) Biocontrol of Rhizoctonia solani and Sclerotium rolfsii on tomato by delivering antagonistic bacteria through a drip irrigation system. Crop Prot 29(7):663-670

DIVAPRA (Dipartimento di Valorizzazione e Protezione delle Risorse Agro-forestali, Sez. Chimica Agraria, Università di Torino), IPLA (Istituto per le Piante da Legno e l'Ambiente) (1992) Metodi di analisi dei compost, Assessorato Ambiente Regione Piemonte (ed), Torino, IT

DL 75/2010 (2010) Decreto Legislativo 29 aprile 2010, n. 75 of Italian Republic "Riordino e revisione della disciplina in materia di 
fertilizzanti", a norma dell'articolo 13 della Legge 7 luglio 2009 n. 88, Gazzetta Ufficiale n. 121-Supplemento Ordinario n.106, Roma, May 26th

Haas D, Défago G (2005) Biological control of soil-borne pathogens by fluorescent Pseudomonas. Nat Rev Microbiol 3:307-319

Hawke MA, Lazarovits G (1994) Production and manipulation of individual microsclerotia of Verticillium dahliae for use in studies of survival. Phytopathology 84(9):883-890

Huang J, Li H, Yuan H (2006) Effect of organic amendments on Verticillium wilt of cotton. Crop Prot 25(11):1167-1173

Huisman OC (1988) Seasonal colonization of roots of field-grown cotton by Verticillium dahliae and V. tricorpus. Phytopathology 78(6):708-716

IOOC (International Olive Oil Council) (2012) Olivae 117, pp 42 Available from: http://www.internationaloliveoil.org/store/index/ 48-olivae-publications (last accessed November 2012)

Jiménez-Díaz RM, Tjamos EC, Cirulli M (1998) Verticillium wilt of major tree hosts: olive. In: Hiemstra JA, Harris DC (eds) A compendium of Verticillium wilts in tree species Pousen and Looijen. Wageningen, The Netherlands, pp 13-16

Lima G, De Cicco V (2006) Integrated strategies to enhance biological control of postharvest diseases. In: Benkeblia N, Shiomi N (eds) Advances in post-harvest technologies for horticultural crops, vol 1., Research SignpostKerala, India, pp 173-194

Lima G, De Curtis F, Donghia AM, Nigro F (2007) Comparison between real time PCR and semi-selective medium in monitoring Verticillium dahliae microsclerotia in the olive rhizosphere and suppression of the pathogen by compost. IOBC/WPRS Bull 30(9):221-224

Lima G, Piedimonte D, De Curtis F, Elgelane A, Nigro F, D’Onghia AM, Alfano G, Ranalli G (2008) Suppressive effect of cured compost from olive oil by-products towards Verticillium dahliae and other fungal pathogens. Acta Hortic 791:585-591

López-Piñeiro A, Murillo S, Barreto C, Muñoz A, Rato JM, Albarrán A, García A (2007) Changes in organic matter and residual effect of amendment with two-phase olive-mill waste on degraded agricultural soils. Sci Total Environ 378(1-2):84-89

Malandraki I, Tjamos SE, Pantelides IS, Paplomatas EJ (2008) Thermal inactivation of compost suppressiveness implicates possible biological factors in disease management. Biol Control 44(2):180-187

Martin FN (2003) Development of alternative strategies for management of soilborne pathogens currently controlled with methyl bromide. Annu Rev Phytopathol 41:325-350

Mercado-Blanco J, Rodriguez-Jurado D, Hervas A, Jiménez-Díaz RM (2004) Suppression of Verticillium wilt in olive planting stocks by rootassociated fluorescent Pseudomonas spp. Biol Control 30:474-486

Murphy J, Riley JP (1962) A modified single solution method for the determination of phosphate in natural waters. Anal Chim Acta 27:31-36

Nelson EB, Boehm MJ (2002) Microbial mechanics of composted induced disease suppression. Part II. Biocycle 43(7):45-47

Nigro F, Schena L, Gallone P (2002) Real-time diagnosis of Verticillium wilt of olive by Scorpion-PCR. In: Proceedings International Conference Oliviculture, VI Giornate Scientifiche SOI, Spoleto, Italy, April 23-25, pp 454-461

Nigro F, Gallone P, Romanazzi G, Schena L, Ippolito A, Salerno MG (2005) Incidence of Verticillium wilt on olive in Apulia and genetic diversity of Verticillium dahliae isolates from infected trees. J Plant Pathol 87(1):13-23

Noble R, Coventry E (2005) Suppression of soilborne plant diseases with composts: a review. Biocontrol Sci Techn 15(1):3-20

Ntougias S, Papadopolou KK, Zervakis GI, Kavroulakis N, Ehaliotis C (2008) Suppression of soil-borne pathogens of tomato by composts derived from agro-industrial wastes abundant in Mediterranean regions. Biol Fert Soils 44(8):1081-1090
Pane C, Spaccini R, Piccolo A, Scala F, Bonanomi G (2011) Compost amendments enhance peat suppressiveness to Pythium ultimum, Rhizoctonia solani and Sclerotinia minor. Biol Control 56(2):115-124

Pullman GS, de Vay JE, Garber RH (1981) Soil solarization and thermal death: logarithmic relationship between time and temperature for four soilborne plant pathogens. Phytopathology 71:959-964

Ranalli G, Bottura G, Taddei P, Garavani M, Marchetti R, Sorlini C (2001) Composting of solid and sludge residues from agricultural and food industries. Bio-indicators of monitoring and compost maturity. J Environ Sci Heal A 36(4):415-436

Saadi I, Laor Y, Medina S, Krassnovsky A, Raviv M (2010) Compost suppressiveness against Fusarium oxysporum was not reduced after one-year storage under various moisture and temperature conditions. Soil Biol Biochem 42(4):626-634

Sambrook J, Fritsch EF, Maniatis T (1989) Molecular cloning: a laboratory manual, 2nd edn. Cold Spring Harbor Laboratory, Cold Spring Harbor, NY, USA

Schena L, Nigro F, Ippolito A (2002) Identification and detection of Rosellinia necatrix by conventional and real-time scorpion-PCR. Eur J Plant Pathol 108:355-366

Schena L, Nigro F, Ippolito A (2004) Real-time PCR detection and quantification of soilborne fungal pathogens: the case of Rosellinia necatrix, Phytophthora nicotianae, P. citrophthora, and Verticillium dahliae. Phytopathol Mediterr 43:273-280

Schoffelmeer EAM, Klis FM, Sietsma JH, Cornelissen BJC (1999) The cell wall of Fusarium oxysporum. Fungal Genet Biol 27(2-3):275-282

Senesi N, Plaza C, Brunetti G, Polo A (2007) A comparative survey of recent results on humic-like fractions in organic amendments and effect on native soil humic substances. Soil Biol Biochem 39(6): 1244-1262

Sequi P, De Nobili M, Leita L, Cercignani G (1986) A new index of Humification. Agrochimica 30:175-179

Singleton VL, Sullivan AR, Kramer C (1971) An analysis of wine to indicate aging in wood or treatment with wood chips or tannic acid. Am J Enol Viticult 22:161-197

Skrobek A, Boss D, Défago G, Butt TM, Maurhofer M (2005) Evaluation of different biological test system to assess the toxicity of metabolites from fungal biocontrol agents. Toxicol Lett 161(1):43-52

van der Gaag DJ, van Noort FR, Stapel-Cuijpers LHM, de Kreij C, Termorshuizen AJ, van Rijn E, Zmora-Nahum S, Chen Y (2007) The use of green waste compost in peat-based potting mixtures: fertilization and suppressiveness against soilborne diseases. Sci Hort Amsterdam 114(4):289-297

Vitullo D, De Curtis F, Di Pietro A, Lima G (2008) Exploring the interaction between bacterial biocontrol agents and genetically characterized mutants of Fusarium oxysporum. J Plant Pathol 90:42-43

Vitullo D, Di Pietro A, Romano A, Lanzotti V, Lima G (2012) Role of new bacterial surfactins in the antifungal interaction between Bacillus amyloliquefaciens and Fusarium oxysporum. Plant Pathol 61(4):689-699

Walker DJ, Bernal MP (2008) The effects of olive mill waste compost and poultry manure on the availability and plant uptake of nutrients in a highly saline soil. Bioresource Technol 99(2):396-403

Whitcombe D, Theaker J, Guy SP, Brown T, Little S (1999) Detection of PCR products using self-probing amplicons and fluorescence. Nat Biotechnol 17:804-807

Yaseen T, D'Onghia A, Ippolito A, Nigro F (2009) Microbial antagonists and compost-based growing media affect the growth of olive plantlets and the inoculum density of Verticillium dahliae microsclerotia. In: Proceedings of 10th International Verticillium Symposium, November 16-20, Corfu Island, Hellas, 87

Yogev A, Raviv M, Giora K, Hadar Y, Cohen R, Benny K, Katan J (2009) Suppression of bacterial canker of tomato by composts. Crop Prot 28(1):97-103

Zucconi F, Pera A, Forte M, de Bertoldi M (1981) Evaluating toxicity of immature compost. Biocycle 22:54-57 